\title{
Effect of Puddling and Compaction on Water Requirements of Rice at Hamelmalo, Eritrea
}

\author{
Bahlbi Goitom, Ramesh Prasad Tripathi*, Woldeselassie Ogbazghi, Tesfalem Weldeslassie \\ Department of Land Resources and Environment, Hamelmalo Agricultural Colleg, Keren, Eritrea \\ Email: "rp.tripathi52@gmail.com, atesfaweld333@gmail.com,bwogbazghi@gmail.com
}

Received 23 February 2016; accepted 25 March 2016; published 29 March 2016

Copyright (C) 2016 by authors and Scientific Research Publishing Inc.

This work is licensed under the Creative Commons Attribution International License (CC BY). http://creativecommons.org/licenses/by/4.0/

(c) () Open Access

\section{Abstract}

Eritrean farmers can cultivate rice by harvesting runoff from $>\mathbf{8 2} \%$ available non-agricultural land in agricultural watersheds for crop use and reducing percolation through optimization of tillage. Experiments were conducted with NERICA rice, N11, to optimize irrigation requirements and puddling and compaction to reduce percolation. Experimental field was adjacent to Anseba River at downstream end of the watershed and a pond on the upstream to intercept runoff. Irrigation treatments were runoff farming with maximum runoff application depth of $10 \mathrm{~mm}\left(\mathrm{I}_{1}\right)$, and $50 \mathrm{~mm}$ irrigation two $\left(I_{2}\right)$, five $\left(I_{3}\right)$, and seven $\left(I_{4}\right)$ days after disappearance of ponded water in main plots and puddling by one $\left(\mathrm{T}_{1}\right)$, two $\left(\mathrm{T}_{2}\right)$ and three $\left(\mathrm{T}_{3}\right)$ passes of puddler and compaction by three $\left(\mathrm{T}_{4}\right)$, four $\left(T_{5}\right)$ and five $\left(T_{6}\right)$ passes of $600 \mathrm{~kg}$ roller in sub plots in 3 replications. Soil profile was loam in the surface $0.45 \mathrm{~m}$ and coarse sandy loam below forming porous belt. Soil submergence was difficult to maintain, but water table was developed in soil profile due to inflow of seepage from the river and pond. Depth to the water table was within $1.5 \pm 0.1 \mathrm{~m}$ for $>2$ months and receded down to $1.7 \mathrm{~m}$ by crop maturity. Soil wetness was near field capacity around $0.7 \mathrm{~m}$ depth and increased below due to natural sub-irrigation from the water table. Rice roots penetrated $0.8 \mathrm{~m}$ in the puddled plots and $0.7 \mathrm{~m}$ in the compacted plots. Residual soil moisture of $135-146 \mathrm{~mm} \cdot \mathrm{m}^{-1}$ after rice harvesting provides opportunity for planting rapeseed mustered following rice. Puddling was superior to compaction in loam soil. Puddling twice and irrigation $50 \mathrm{~mm} 7$ days after ponded water vanished from surface was sufficient for optimum rice grain yield of $4346 \mathrm{~kg} \cdot \mathrm{ha}^{-1}$ and straw yield of $4458 \mathrm{~kg} \cdot \mathrm{ha}^{-1}$. Optimum puddling and irrigation schedules reduced crop duration by 6 days without significantly affecting yield. Production function showed that rice grain yield of $4789 \mathrm{~kg}$ ha $^{-1}$ could be obtained by $1009 \mathrm{~mm}$ applied water through rainfall and irrigation.

\section{Keywords}

Compaction, Irrigation, NERICA Rice, Puddling, Runoff Farming, Water Table

\footnotetext{
${ }^{*}$ Corresponding author.
}

How to cite this paper: Goitom, B., Tripathi, R.P., Ogbazghi, W. and Weldeslassie, T. (2016) Effect of Puddling and Compaction on Water Requirements of Rice at Hamelmalo, Eritrea. Computational Water, Energy, and Environmental Engineering, 5, 27-37. http://dx.doi.org/10.4236/cweee.2016.52003 


\section{Introduction}

Rice (Oryza sativa L.) is among the oldest and widely grown food crops in the world [1]. It is cultivated on about $144 \mathrm{~m}$ ha each year and is food for about half the world population [2]. Rice demand in sub-Sahara region is growing at a rate of $6 \%$ per annum, but average yields have been stagnant around $1.4 \mathrm{t} \cdot \mathrm{ha}^{-1}$ as against $>4$ $\mathrm{t} \cdot \mathrm{ha}^{-1}$ in Asia and $>6 \mathrm{t} \cdot \mathrm{ha}^{-1}$ in China [3]-[5]. Low yields in sub-Sahara are credited to arid to semiarid conditions, but evapotranspiration of rice under different climate and length of growing periods ranges from $450-700 \mathrm{~mm}$ [6], which is almost equal to sorghum and pearl millet (450 - $650 \mathrm{~mm})$ and lesser than maize (500 - $850 \mathrm{~mm})$, cotton (700 - $1300 \mathrm{~mm})$ and sugarcane $(1500$ - $2500 \mathrm{~mm})$ grown in some pockets in western Eritrea. Unfortunately rice is a semiaquatic plant requiring soil water regime from field capacity to shallow submergence in which considerable water necessarily percolates beyond root zone [7]-[10]. Rice is also cultivated where flood water may be several meters deep and, in the extreme, as an upland cereal [11] [12]. Irrigation intervals ranged from 3 - 8 days for optimum rice yields under limited water supply conditions in different soils and climates [7] [13] [14]. Similarly percolation rates in different soils and management conditions ranged from $1-25 \mathrm{~mm} \cdot \mathrm{d}^{-1}$ [8] [10]. In Laos, 112-day crop required $1389 \mathrm{~mm}$ water, of which 7.3, 2.4 and $2.7 \mathrm{~mm} \cdot \mathrm{d}^{-1}$ were percolation, transpiration and evaporation, respectively [15]. In general rice may require 1000 - $1500 \mathrm{~mm}$ water on heavy soils for a short duration variety, 1500 - 2000 mm on medium soils for medium duration variety during monsoon or early spring season and 2000 - $2500 \mathrm{~mm}$ on light soils for long duration variety during summer season [16]. Average water requirements of New Rice for Africa (NERICA) under deficit irrigation conditions were about $800 \mathrm{~mm}$ for 115 - 120 days crop yielding 2 - $4 \mathrm{t} \cdot \mathrm{ha}^{-1}$ [17] [18].

Scarcity of water demands further studies on reducing water requirements and breeding for early maturing and drought tolerant varieties to match rice demand and production in the world [19]. Soil puddling and compaction are common field practices to reduce percolation losses. Puddling is plowing the field under water-saturated conditions to enhance water retention and reduce deep percolation [20] [21]. During puddling, soil undergoes two types of deformations: first, due to normal stress which is associated with compression and second, the tangential stress causing shear [22]. The two forces applied during puddling loosen and break soil clods and compact the subsoil. A typical soil profile of puddled rice soil thus consists of i) a ponded water layer, ii) a muddy layer with moderate resistance to water flow, iii) a compacted hard layer with large resistance to water flow and iv) a non-puddled subsoil of high saturated conductivity but having unsaturated flow of water [20]. Knowledge of puddling intensity, necessary to achieve optimum soil puddle conducive to early establishment and growth of rice with minimum deterioration of soil aggregates, has been a challenge for researchers and farmers [23]. Two passes of rotary puddler optimized yield with minimum deterioration of soil structure in silty clay loam [24] [25]. About 100 - 150 mm water was necessary for soil puddling [26].

Compaction reduces pore size distribution to meet soil physical requirements of rice. To achieve desired density, soil is plowed, harrowed, fertilized and brought to optimum moisture content for compaction by one to more passes of a cylindrical roller of known dimension and mass over the soil surface. The field is then flooded and rice seedlings are transplanted [7] [10]. Soil compaction is a low cost method to reduce percolation loss [27] [28]. Compaction in sandy soils improved water retention, reduced nutrient leaching, saved 15\% - 36\% irrigation water and raised productivity by $30 \%$ - 50\% [29]-[31]. Compaction reduced infiltration rate by $40 \%-60 \%$ in low permeable soils and 70\% - 80\% in highly permeable soils [27] [32]. Soil compaction by 2, 6, 10, and 16 passes of $1.3 \mathrm{~m}$ long, $0.7 \mathrm{t}$ roller at proctor moisture content $(\approx 11.9 \%)$ achieved bulk densities of 1.7, 1.75, 1.79, and $1.84 \mathrm{Mg} \cdot \mathrm{m}^{-3}$, respectively, in surface $60 \mathrm{~mm}$ soil. About $0.99 \mathrm{~m}$ water was saved by compaction in directseeded rice crop [27]. Puddling and compaction were equally effective in reducing percolation rate to a satisfactory level in soils with less than $70 \%$ sand, but compaction was more effective when sand content exceeded $70 \%$ [33]. Humphreys et al. [34] reported that puddling reduced deep percolation from an average of $3400 \mathrm{~mm}$ in control to 300 and $500 \mathrm{~mm}$, respectively under high and low intensity of puddling. Nitrogen recovery in rice fields may range from $25 \%$ - $41 \%$ of applied fertilizer nitrogen under various management conditions due to leaching, denitrification and volatilization losses [35] [36]. Javid et al. [37] observed significantly high yields under compaction to $1.67 \mathrm{Mg} \cdot \mathrm{m}^{-3}$ than puddling. Cost benefit analysis also showed superiority of compaction than puddling in coarse textured soils. Bajpai and Tripathi [9] reported that both puddling and non-puddling were equally effective on rice performance in Mollisols associated with shallow water tables. Location specific soil conditions would thus have significant influence on tillage requirements, which should be evaluated before planning rice cultivation. 
Although practices to minimize high percolation from rice fields were known and possibilities of runoff farming existed in Eritrea [38], no systematic efforts were made to cultivate rice due to fear of its high water requirements, inadequate rainfall and highly permeable soils. Some experiments were conducted by National Agricultural Research Institution (NARI), Eritrea, using NERICA varieties, but conclusions were discouraging [39]. On the contrary, experiments at Hamelmalo Agricultural College under rainfed and life-saving irrigations showed encouraging results [40]. NERICA is a cross of African (Oryza glaberrima) and Asian rice (Oryza sati$v a$ ), which has been successfully grown in Africa under limited irrigation conditions [5] [17] [28] [40]. Inadequate rainfall in Eritrea can be supplemented by runoff harvested as additional water for crop use from $>82 \%$ non-agricultural lands in the watersheds [37] [41]-[43]. Objective of this study was to optimize soil compaction and puddling intensity to reduce percolation loss and irrigation requirements of rice under semiarid conditions of Hamelmalo.

\section{Methods and Material}

\subsection{Soil}

Experiments were conducted in 2013 and 2014 at Hamelmalo Agricultural College in a field at downstream end of a watershed adjacent to Anseba River. A pond was constructed adjacent to rice field on the upstream side to intercept runoff from the remaining part of the watershed for use by the crop [43]. Hamelmalo Agricultural College is located $\left(15^{\circ} 52^{\prime} 20.6^{\prime \prime} \mathrm{N}\right.$ and $38^{\circ} 27^{\prime} 57.6^{\prime \prime} \mathrm{E}$ at $\left.1280 \mathrm{msl}\right)$ in the semiarid region of Eritrea. Annual rainfall in the past seven years ranged from $370-663.1 \mathrm{~mm}$ with a mean of $488 \mathrm{~mm}$ and average annual pan evaporation of $1931 \mathrm{~mm}$. Highest mean monthly temperature occurred in May $\left(35.7^{\circ} \mathrm{C}\right)$ and lowest in January $\left(11.1^{\circ} \mathrm{C}\right)$. Total rainfall was $388 \mathrm{~mm}$ in 2013 and $429 \mathrm{~mm}$ in 2014 (Figure 1). Monsoon season in the two cropping years started from third week of June and ended by third week of September.

Experimental soil was loam with $45.4 \% \mathrm{~s}$ and, $38.8 \%$ silt and $15.8 \%$ clay and organic matter content of $0.06 \%$. Average bulk density of $0-0.2 \mathrm{~m}$ soil was $1.34 \mathrm{Mg} \cdot \mathrm{m}^{-3}$ and field capacity and saturation percentage were $24.5 \%$ and $47.3 \%$ respectively. Soil $\mathrm{pH}$ was 8.06 and EC $0.17 \mathrm{dS} \cdot \mathrm{m}^{-1}$. Exchangeable $\mathrm{Ca}, \mathrm{Mg}, \mathrm{K}$ and $\mathrm{Na}$ were 21, 5, 0.2 and $0.5 \mathrm{cmol}(+) \mathrm{kg}^{-1}$, respectively.

\subsection{Experimental Details}

Field experiment was conducted using NERICA rice variety N11. The experiment was laid out in split plot design with supplementary irrigations in main plots and tillage in sub plots in three replications. Irrigation treatments were runoff farming (RF) with maximum water application depth of $0.1 \mathrm{~m}\left(\mathrm{I}_{1}\right)$, and $0.05 \mathrm{~m}$ irrigation two $\left(\mathrm{I}_{2}\right)$, five $\left(\mathrm{I}_{3}\right)$, and seven $\left(\mathrm{I}_{4}\right)$ days after disappearance of ponded water. Tillage treatments were puddling by one $\left(T_{1}\right)$, two $\left(T_{2}\right)$ and three $\left(T_{3}\right)$ passes of puddler and compaction by three $\left(T_{4}\right)$, four $\left(T_{5}\right)$ and five $\left(T_{6}\right)$ passes of roller of length $1.3 \mathrm{~m}$ and weight $600 \mathrm{~kg}$. Puddling in the plots was done manually using spade representing local plow and a wooden plank. Each plot was $3 \mathrm{~m} \times 4 \mathrm{~m}$ with $1.5 \mathrm{~m}$ passage between plots and replications. Bunds of height $0.30 \mathrm{~m}$ were made around each plot to prevent runoff. A water harvesting canal was constructed around the field about $1.5 \mathrm{~m}$ away from the plots to store any runoff from the surrounding area and use

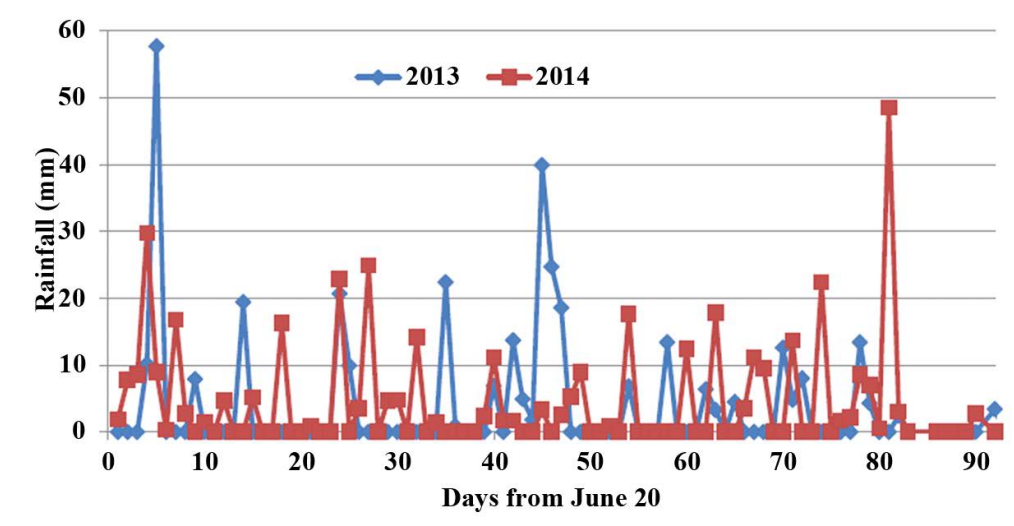

Figure 1. Rainfall during the crop season of 2013 and 2014. 
for irrigation in experimental plots whenever necessary.

Twenty-one days old single seedlings were transplanted in puddled and compacted plots in the first week of July at $0.2 \mathrm{~m}$ interval between rows and $0.15 \mathrm{~m}$ within row. About $100 \mathrm{~mm}$ irrigation was applied for puddling that maintained 40 - $60 \mathrm{~mm}$ submergence during transplanting. Shallow submergence of $10-20 \mathrm{~mm}$ was maintained in all the plots by irrigation during rainless periods for about 10 days for initial establishment. Nursery was planted in June first week, which reduced crop duration with low water demand compared to that in the field and assured plant density by transplanting. Fertilizers applied were urea and DAP at the rate of $120 \mathrm{~kg} \mathrm{~N}$ and $60 \mathrm{~kg} \cdot \mathrm{P} \cdot \mathrm{ha}^{-1}$. Entire DAP was applied as basal dose during last puddling operation and the remaining $\mathrm{N}$ was applied through urea in two equal splits at 20 days interval from transplanting. Weeding was done 3 times at an interval of 15 - 20 days from transplanting. Copper disulphide (0.25\%) was sprayed to recover Cu deficiency noticed during the panicle initiation stage. Termite problem was observed especially in the runoff irrigated plots, which was controlled by Cypermethrin and Tafaban applications. Measurements were made of root length density, effective tillers, water content, water table, and yield. Tillers with grain bearing ears were counted as effective tillers per plant in three hills in each plot. Grain and straw yields were determined by harvesting central $2 \mathrm{~m}$ $\times 2 \mathrm{~m}$ plot. The harvested biomass was dried in the field for 3 days and weighed before threshing manually. Weight of grain was taken at $14 \%$ seed moisture and expressed in $\mathrm{kg} \cdot \mathrm{ha}^{-1}$. Total above ground biomass minus grain yield was the straw yield.

\subsection{Root Length Density}

Root length density (RLD) and \% root distribution were determined at harvesting by line intersection method of Tennant [44]. Core samples were drawn from each treatment in $0.15 \mathrm{~m}$ depth increments down to root depth by placing $0.1 \mathrm{~m}$ diameter root core sampler over the harvested hill. The samples were washed and number of roots with vertical and horizontal grid lines of $10 \mathrm{~mm}$ was counted by spreading on a dish with a film of water to calculate RLD $\left(\mathrm{cm}^{\circ} \mathrm{cm}^{-3}\right)$ and \% root distribution as

$$
\operatorname{RLD}=\frac{R}{V}
$$

where $V$ is soil core volume $\left(\mathrm{cm}^{3}\right)$ and $R$ is root length $(\mathrm{cm})$ expressed as

$$
R=\frac{11}{14} N \text { Grid units }
$$

where $N$ is number of intersections. Percent root distribution was calculated as

$$
\% \text { Root distribution }=\frac{\text { RLD in ith layer }}{\text { Total RLD }}
$$

Rice roots were observed down to $0.8 \mathrm{~m}$ and, therefore, soil moisture was determined from $1 \mathrm{~m}$ profile. Soil moisture at harvesting was the residual moisture in soil after rice harvesting.

\section{Results and Discussion}

\subsection{Bulk Density Variation with Depth in Rice Field}

Two-year average bulk density in puddled rice field was $1.35 \mathrm{Mg} \cdot \mathrm{m}^{-3}$ in surface $0.1 \mathrm{~m}$ layer, which increased to $1.42 \mathrm{Mg} \cdot \mathrm{m}^{-3}$ in $0.1-0.2 \mathrm{~m}$ layer, $1.37 \mathrm{Mg} \cdot \mathrm{m}^{-3}$ in $0.2-0.3 \mathrm{~m}$ and $1.39 \mathrm{Mg} \cdot \mathrm{m}^{-3}$ in $0.3-0.4 \mathrm{~m}$ layer (Figure 2). Changes in bulk density in $0-0.2 \mathrm{~m}$ layer were due to puddling in 2 years. There was no change in density below $0.2-0.3 \mathrm{~m}$ layer due to puddling or compaction. Soil texture below $0.45 \mathrm{~m}$ was coarse sandy loam. Bulk density was $1.51 \mathrm{Mg} \cdot \mathrm{m}^{-3}$ in $0.4-0.5 \mathrm{~m}$ layer and $1.58 \mathrm{Mg} \cdot \mathrm{m}^{-3}$ in 0.7 to $0.8 \mathrm{~m}$ layer. Increasing coarseness of texture below $0.4 \mathrm{~m}$ depth indicates existence of porous belt in the soil profile.

\subsection{Water Table Fluctuation and Wetness in the Root Zone}

Rice field being adjacent to Anseba River on the downstream side and pond on the upstream side and existence of porous belt below $0.45 \mathrm{~m}$ depth allowed considerable seepage in the rice field. This resulted rise in water table 


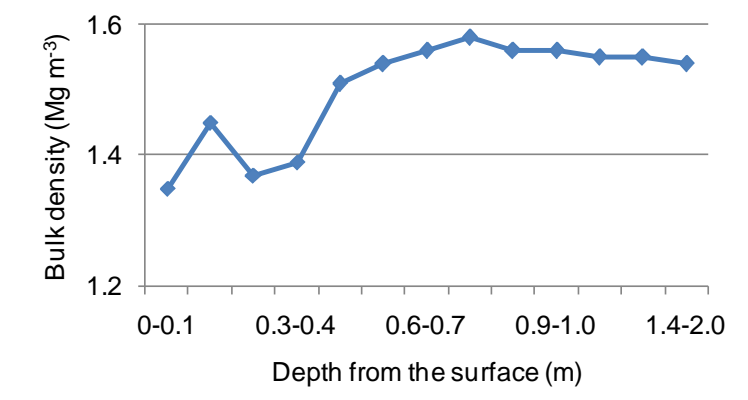

Figure 2. Bulk density variation with depth in the rice field.

from $3.25 \mathrm{~m}$ depth a week before rice transplanting to $1.4 \mathrm{~m}$ by end of August (Figure 3). High percolation in rice field might have also added to rising groundwater table. The water table was within $1.5 \pm 0.1 \mathrm{~m}$ for about 2 months, which receded down to $1.7 \mathrm{~m}$ by harvesting.

Rising groundwater table increased wetness in soil profile above the water table due to upward movement of water by capillarity (Figure 4). Soil moisture content below $0.7 \mathrm{~m}$ depth was near field capacity and showed increasing wetness with depth. As a result, part of rice roots might be receiving water from the water table. Thus groundwater table could serve as natural source of sub-irrigation to rice crop as evidenced by relatively greener rainfed crop until maturity (Figure 5). Although surface soil was drier forming fine cracks yet soil near 0.7 - 0.8 m was above field capacity moisture (Figure 4).

\subsection{Growth Pattern of Rice}

Mean plant height at harvesting ranged from 0.87 to $1.06 \mathrm{~m}$ due to tillage and 0.93 to $1 \mathrm{~m}$ due to irrigation (Table 1). High puddling intensity encouraged plant height significantly whereas high compaction discouraged it. Mean days to maturity from transplanting ranged from 106 to 118 days due to tillage and 111 to 117 days due to irrigations. Mean days to maturity was significantly higher under compaction (116 - 118 days) than puddling (106 - 110 days). Maturity was also delayed significantly (117 days) by irrigations 2 days after water vanished from the surface $\left(\mathrm{I}_{2}, 2 \mathrm{DAWV}\right)$. Slower seedling establishment and initial growth might have added to delayed maturity under compaction than puddling. Mean tillers per plant ranged from 10 - 12 due to irrigations and 9 15 due to tillage. Tillering was favored by lower puddling $\left(T_{1}, T_{2}\right)$ and higher compaction $\left(T_{4}, T_{5}\right)$ levels. Poor seedling survival and growth under higher compaction was greatly compensated by tillering.

\subsection{Rooting Pattern of Rice}

Rice roots penetrated down to $0.8 \mathrm{~m}$ under puddling and to $0.7 \mathrm{~m}$ under compaction but maximum root concentration was in the surface $0.1 \mathrm{~m}$ (Figure 6). About $72.2 \%$ roots were in $0-0.1 \mathrm{~m}$ layer under puddling and $66.9 \%$ under compaction. However, roots in $0.2-0.7 \mathrm{~m}$ layer were higher under compaction than puddling. Root concentration below $0.5 \mathrm{~m}$ was $<1 \%$ both under compaction and puddling. Roots of NERICA rice down to $0.8 \mathrm{~m}$ were also reported by Tripathi et al. [40] in a sandy loam under rainfed and limited irrigation conditions. Bajpai and Tripathi [9] also observed better root growth in puddled soils.

\subsection{Grain Yield of Rice}

Mean grain yield due to puddling was at par and significantly higher under 2 passes of puddler (4046 kg ha $^{-1}$ ) than all levels of compaction in 2 years (Table 2). Mean yield was also at par among the compaction levels and was highest (3406 $\mathrm{kg} \cdot \mathrm{ha}^{-1}$ ) under 4 passes of roller, which was also at par with 1 and 3 puddlings. Similarly mean yields due to irrigations were at par in $\mathrm{I}_{2}$ and $\mathrm{I}_{3}$ and significantly greater than in $\mathrm{I}_{1}$ (runoff farming, RF). In $\mathrm{I}_{1}$, runoff was available for irrigation only for a day after rainfall because pond was draining fast and thus water availability to the crop was controlled by rainfall event. Interaction effects showed that rice yield in $\mathrm{I}_{2} \mathrm{~T}_{2}$ was highest (4865 kg·ha ${ }^{-1}$ ) and at par with that in $\mathrm{I}_{2}$ and $\mathrm{I}_{3}$ at all levels of puddling and also in $\mathrm{I}_{4}$ under $\mathrm{T}_{2}$ and $\mathrm{T}_{3}$ levels of puddling. Results thus show that $50 \mathrm{~mm}$ irrigation 7 days after water vanished (DAWV) from surface of the plot puddled twice was sufficient for optimum yield of rice in loam soil at outlet end of the watershed adjacent to Anseba River. Among compaction levels yield was at par in $\mathrm{T}_{4}$ and $\mathrm{T}_{5}$ at all levels of irrigation and also 


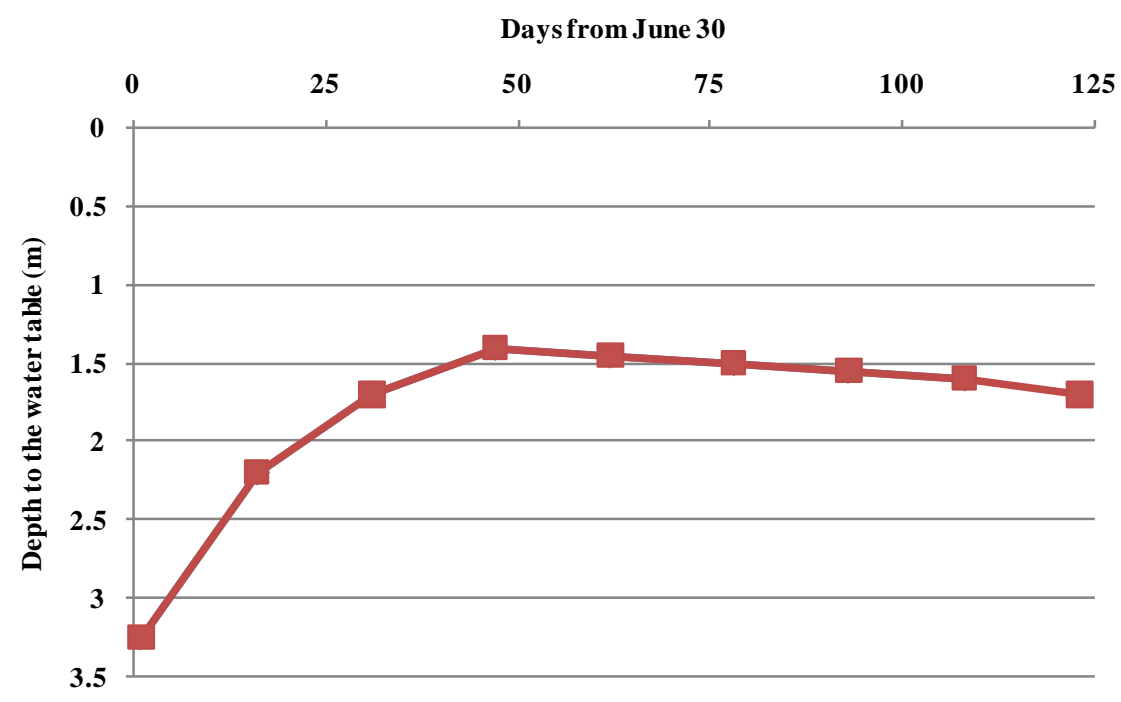

Figure 3. Two-year average water table fluctuations in the rice field.

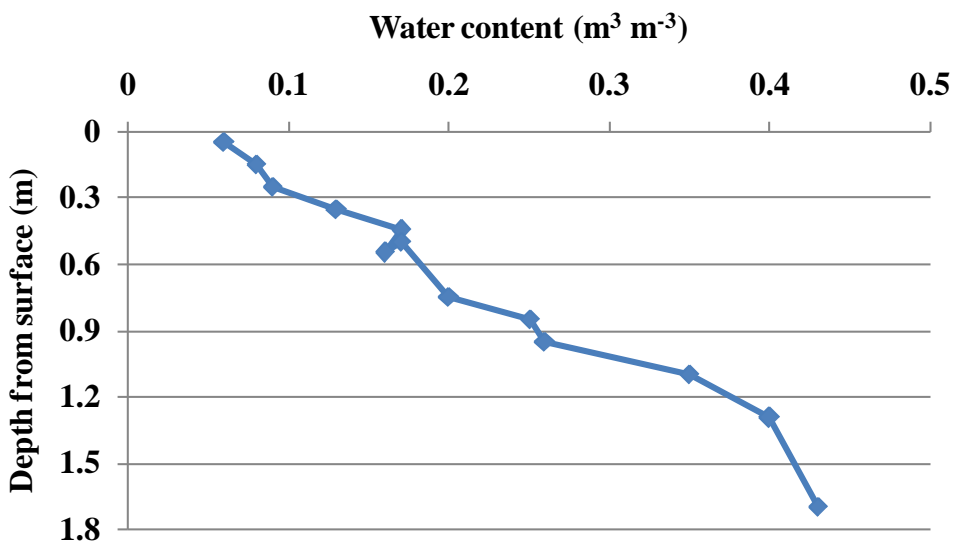

Figure 4. Soil moisture profile above groundwater table during mid-September.

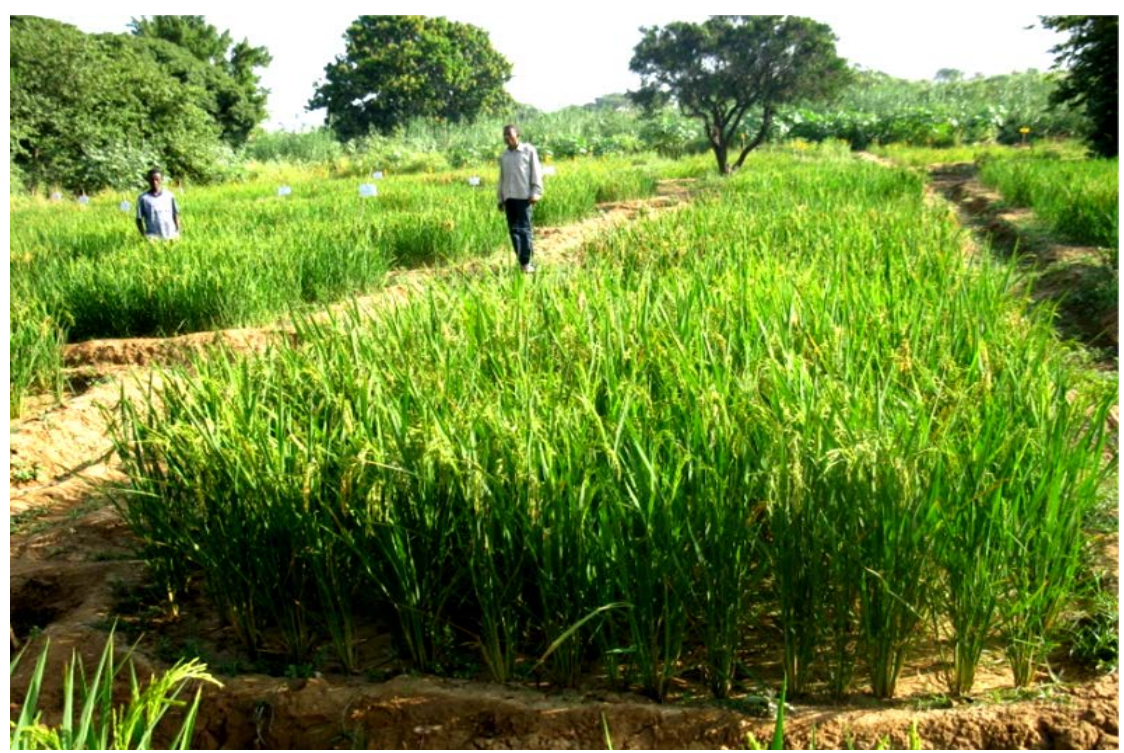

Figure 5. Dry soil surface but greener crop. 


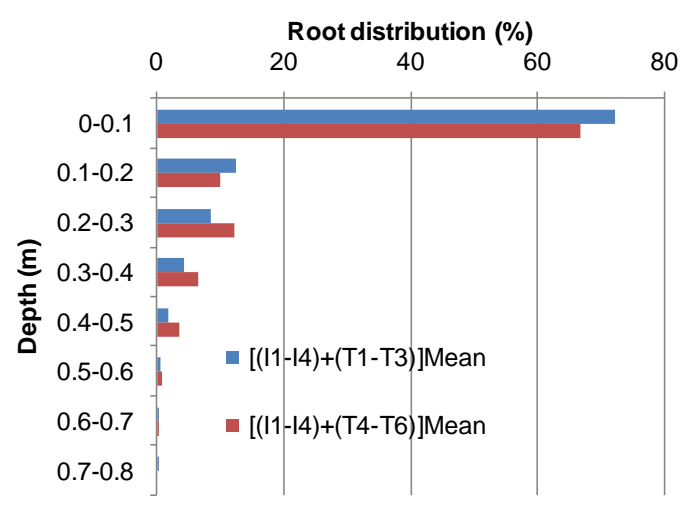

Figure 6. Average rice root distribution in soil.

Table 1. Mean plant growth parameters at maturity under different tillage and irrigations.

\begin{tabular}{cccccccc}
\hline $\begin{array}{c}\text { Tillage } \\
\text { treatments }\end{array}$ & $\begin{array}{c}\text { Plant } \\
\text { height, } \mathrm{m}\end{array}$ & $\begin{array}{c}\text { Days to } \\
\text { maturity }\end{array}$ & Tillers/plant & $\begin{array}{c}\text { Irrigation } \\
\text { treatments }\end{array}$ & $\begin{array}{c}\text { Plant } \\
\text { height, } \mathrm{m}\end{array}$ & $\begin{array}{c}\text { Days to } \\
\text { maturity }\end{array}$ & Tillers/Plant \\
\hline $\mathrm{T}_{1}$ (1 pass puddler) & 1.00 & 110 & 11 & $\mathrm{I}_{1}(\mathrm{RF})$ & 0.93 & 111 & 12 \\
$\mathrm{~T}_{2}$ (2 pass puddler) & 1.03 & 110 & 10 & $\mathrm{I}_{2}$ (2DAWV) & 0.98 & 117 & 10 \\
$\mathrm{~T}_{3}$ (3 pass puddler) & 1.06 & 106 & 9 & $1_{3}$ (5DAWV) & 1.00 & 114 & 11 \\
$\mathrm{~T}_{4}$ (3 pass roller) & 0.96 & 116 & 9 & $\mathrm{I}_{4}$ (7DAWV) & 0.98 & 112 & 11 \\
$\mathrm{~T}_{5}$ (4 pass roller) & 0.90 & 118 & 12 & LSD (5\%) & $\mathrm{NS}$ & 2 & $\mathrm{NS}$ \\
$\mathrm{T}_{6}$ (5 pass roller) & 0.87 & 118 & 15 & & & & \\
LSD (5\%) & 0.03 & 2 & 1 & & & & \\
\hline
\end{tabular}

Table 2. Two-year average grain yield of rice under differenttillage and irrigationschedules.

\begin{tabular}{|c|c|c|c|c|c|c|c|}
\hline \multirow{2}{*}{$\begin{array}{l}\text { Irrigation } \\
\text { Treatments }\end{array}$} & \multicolumn{7}{|c|}{ Grain yield $\left(\mathrm{kg} \cdot \mathrm{ha}^{-1}\right)$ at puddling and compaction levels } \\
\hline & $\mathrm{T}_{1}$ (1 pass puddler) & $\begin{array}{l}\mathrm{T}_{2} \text { (2 pass } \\
\text { puddler) }\end{array}$ & $\begin{array}{l}\mathrm{T}_{3} \text { (3 pass } \\
\text { puddler) }\end{array}$ & $\mathrm{T}_{4}$ (3 pass roller) & $\begin{array}{c}\mathrm{T}_{5} \text { (4 pass } \\
\text { roller) }\end{array}$ & $\begin{array}{l}\mathrm{T}_{6} \text { (5 pass } \\
\text { roller) }\end{array}$ & Mean yield \\
\hline $\mathrm{I}_{1}(\mathrm{RF})$ & 2349 & 2537 & 2658 & 1968 & 2208 & 1709 & 2238 \\
\hline $\mathrm{I}_{2}(2 \mathrm{DAWV})$ & 4505 & 4865 & 4764 & 3966 & 3912 & 3878 & 4302 \\
\hline $1_{3}(5 \mathrm{DAWV})$ & 4354 & 4437 & 4332 & 3384 & 3877 & 3101 & 3929 \\
\hline $\mathrm{I}_{4}(7 \mathrm{DAWV})$ & 3924 & 4346 & 4212 & 3513 & 3627 & 3055 & 3795 \\
\hline Mean & 3783 & 4046 & 3992 & 3208 & 3406 & 2936 & \\
\hline Factors & $\mathrm{T}$ & I & T x I & & & & \\
\hline LSD (5\%) & 617 & 437 & 864 & & & & \\
\hline
\end{tabular}

in $T_{6}$ under $I_{2}$. Seedling establishment was delayed under 5 passes of roller perhaps due to compaction. Amount of water used in $\mathrm{I}_{1}(\mathrm{RF})$ and $\mathrm{I}_{4}$ (irrigations 7 DAWV) were almost same but yields were significantly higher in $\mathrm{I}_{4}$ than in $\mathrm{I}_{1}$. These differences reveal that not only the amount of rainfall but its distribution would control rice performance.

\subsection{Straw Yield of Rice}

Mean straw yields due to puddling and 3 and 4 passes of roller were at par but significantly greater than under 5 passes of roller over the 2 years (Table 3 ). Mean straw yields due to irrigations were significantly higher in $\mathrm{I}_{2}$ (irrigations $2 \mathrm{DAWV}$ ) than in $\mathrm{I}_{1}$ and $\mathrm{I}_{4}$. Interaction effects show that straw yields under puddling and 3 and 4 passes of roller were significantly higher in $\mathrm{I}_{2}$ than in $\mathrm{I}_{1}$ and $\mathrm{I}_{4}$. In $\mathrm{I}_{3}$, straw yields under 1 and 2 passes of puddler were 
Table 3. Two-year straw yield of rice under differenttillage and irrigations.

\begin{tabular}{|c|c|c|c|c|c|c|c|}
\hline \multirow{2}{*}{$\begin{array}{l}\text { Irrigation } \\
\text { Treatments }\end{array}$} & \multicolumn{7}{|c|}{ Straw yield $\left(\mathrm{kg} \cdot \mathrm{ha}^{-1}\right)$ at puddling and compaction levels } \\
\hline & $\begin{array}{c}\mathrm{T}_{1} \text { (1 pass } \\
\text { puddler) }\end{array}$ & $\begin{array}{l}\mathrm{T}_{2} \text { (2 pass } \\
\text { puddler) }\end{array}$ & $\begin{array}{c}\mathrm{T}_{3} \text { (3 pass } \\
\text { puddler) }\end{array}$ & $\begin{array}{c}\mathrm{T}_{4} \text { (3 pass } \\
\text { roller) }\end{array}$ & $\begin{array}{c}\mathrm{T}_{5} \text { (4 pass } \\
\text { roller) }\end{array}$ & $\begin{array}{c}\mathrm{T}_{6} \text { (5 pass } \\
\text { roller) }\end{array}$ & Mean yield \\
\hline $\mathrm{I}_{1}(\mathrm{RF})$ & 3430 & 2966 & 2956 & 3212 & 3132 & 2619 & 3053 \\
\hline $\mathrm{I}_{2}(2 \mathrm{DAWV})$ & 5288 & 5416 & 5492 & 5293 & 4848 & 4564 & 5150 \\
\hline $1_{3}(5 \mathrm{DAWV})$ & 4769 & 4969 & 4558 & 4158 & 4509 & 4095 & 4510 \\
\hline $\mathrm{I}_{4}(7 \mathrm{DAWV})$ & 4323 & 4458 & 4453 & 4264 & 4271 & 3640 & 4235 \\
\hline Mean & 4452 & 4452 & 4365 & 4231 & 4190 & 3730 & \\
\hline Factors & $\mathrm{T}$ & I & $\mathrm{T} \times \mathrm{I}$ & & & & \\
\hline LSD (5\%) & 516 & 426 & 794 & & & & \\
\hline
\end{tabular}

also at par with yields in $\mathrm{I}_{2}$ and $\mathrm{I}_{4}$. Grain yield was generally optimum at less than water and nutrients' optima for vegetative growth [10]. Thus puddling and irrigation optima for straw yield should be based on optima for grain yield $\left(\mathrm{T}_{2} \mathrm{I}_{2}\right)$.

\subsection{Water Production Function}

Relationship between applied water (rainfall + irrigation) and grain yield showed a second degree polynomial with highest yield of $4789 \mathrm{~kg} \cdot \mathrm{ha}^{-1}$ at $1009 \mathrm{~mm}$ of applied water (Figure 7). As shown in Table 2, for the same amount of applied water yields were significantly lower under compaction than puddling. Yields were even at par by irrigations every 2 - 7 DAWV perhaps due to proportionately high percolation in more frequently irrigated plots. Much of the irrigation water was applied during September to October when the rice roots had already entered deep into the profile. Despite puddling and compaction, percolation was augmented by enormous earth worm population in the plots forming bio-pores. Earth worms were moving out into bunds upon irrigations or rainfall and retuning back into soil after water vanished from the surface. Applied water on all irrigations was thus vanishing in less than $12 \mathrm{~h}$ and crop yields were not in proportional to applied water. Crop survival and growth was perhaps more due to rice roots penetrating deeper into soil profile wetted to field capacity by water table to meet significant part of plant water demand than irrigations.

\subsection{Residual Moisture after Rice}

Two-year average residual soil moisture ranged from $135 \mathrm{~mm} \cdot \mathrm{m}^{-1}$ in $\mathrm{T}_{1}$ to $146 \mathrm{~mm} \cdot \mathrm{m}^{-1}$ in $\mathrm{T}_{2}$ (Figure 8). In general residual moisture increased with decreasing level of compaction, medium puddling intensity $\left(\mathrm{T}_{2}\right)$ and frequency of irrigations. Greater puddling or compaction allowed greater wetting in surface layers, which was also subject to greater drying and lower percolation and thus lesser residual moisture. Significant residual soil moisture at rice harvesting emphasizes opportunity for cultivating another crop such as rapeseed mustered following rice.

\section{Conclusions}

1) Alluvium deposits near outlet end of watershed in Hamelmalo region are generally finer in texture in surface layers, but coarser in layers below forming more porous subsoil.

2) Soil submergence necessary for rice may be difficult to maintain, but water table may develop due to inflow of water by seepage from river and pond made for water harvesting.

3) Water table could serve as natural source of sub-irrigation to rice crop.

4) NERICA-11 rice roots could penetrate deeper than 0.7 - $0.8 \mathrm{~m}$ under optimum management.

5) Two puddlings were sufficient in loam soil for optimum yield of rice in Hamelmalo region.

6) Irrigating 7 days after $50 \mathrm{~mm}$ ponded water vanished from the surface may produce $4856 \mathrm{~kg} \cdot \mathrm{ha}^{-1}$ rice under optimum management.

7) Maximum rice yield of $4789 \mathrm{~kg} \cdot \mathrm{ha}^{-1}$ could be obtained by application of $1009 \mathrm{~mm}$ water through rainfall and irrigation. 


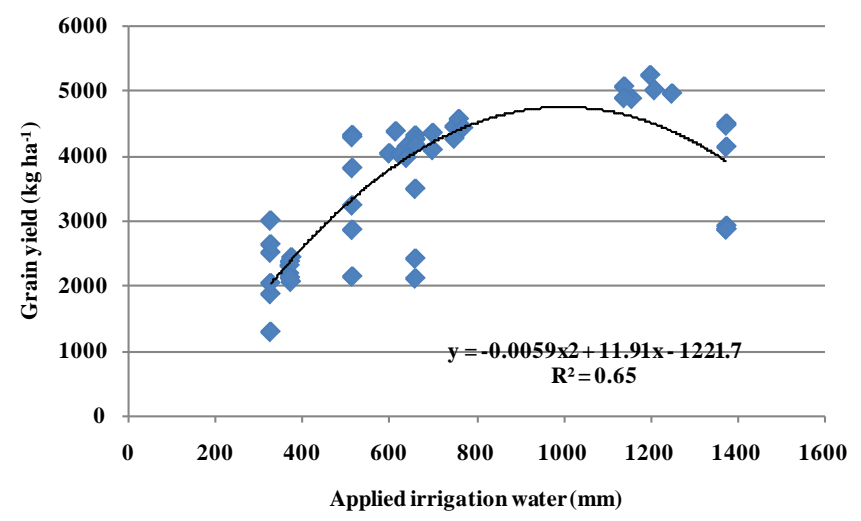

Figure 7. Grain yield as a function of applied irrigation water.

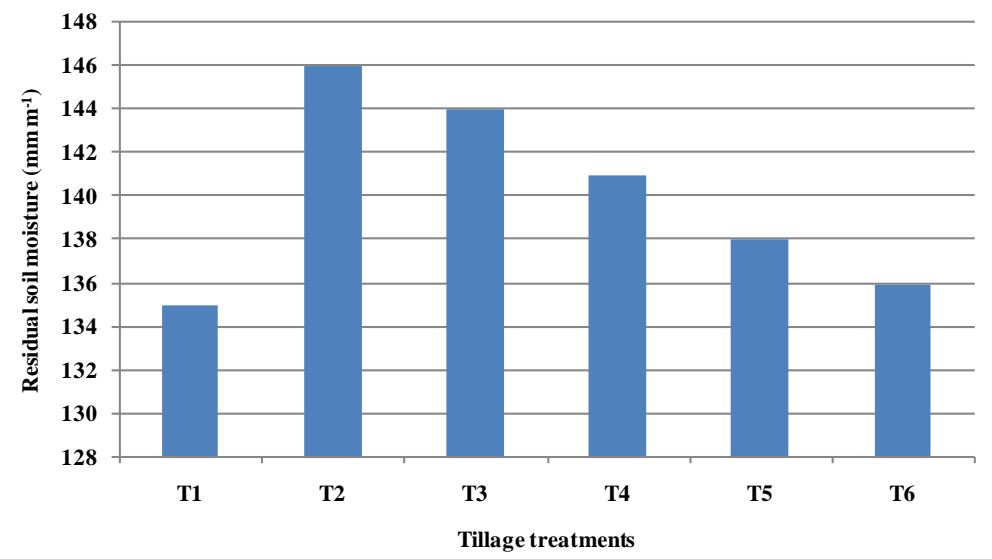

Figure 8. Two-year average residual soil moisture at rice harvesting.

8) Residual soil moisture of 135 - $146 \mathrm{~mm} \cdot \mathrm{ha}^{-1}$ at rice harvesting provides opportunity for planting another crop such as rapeseed mustered following rice.

\section{Acknowledgements}

Senior author is grateful to Ministry of Agriculture, Government of Eritrea for granting leave and Hamelmalo Agriculture College for providing assistance for conducting thesis research. Authors are also grateful to UNDP for providing funds from SGP/GEF grant for carrying out the research.

\section{References}

[1] Zareiforoush, H., Komarizadeh, M.H. and Alizadeh. M.R. (2009) Effect of Moisture Content on Some Physical Properties of Paddy Grains. Research Journal of Applied Sciences, Engineering and Technology, 1, 132-139.

[2] FAO (2013) Riceproduction, Systems (Internet). http://www.fao.org/climatechange/climatesmartpub/66245/en/

[3] WARDA (West Africa Rice Development Association) (2006) Perspective Rice Development in Sub-Saharan Africa. Journal of the Science of Food and Agriculture, 86, 675-677. http://dx.doi.org/10.1002/jsfa.2415

[4] Somado, E.A., Guei, R.G. and Keya, S.O., Eds. (2008) NERICA: The New Rice for Africa-A Compendium. Africa Rice Center. Cotonou; FAO, Rome; Sasakawa Africa Association, Tokyo, 210 p.

[5] Wopereis, M.C.S., Defoer, T., Idinoba, P., Diack, S. and Dugué, M.J. (2009) Participatory Learning and Action Research (PLAR) for Integrated Rice Management (IRM) in Inland Valleys of Sub-Saharan Africa: Technical Manual. WARDA Training Series, Africa Rice Center, Cotonou, 128 p.

[6] Doorenbos, J. and Pruitt, W.O. (1977) Guidelines for Predicting Crop Water Requirements. FAO Irrig. Drain. Pap. 24 (rev. 1977), Food and Agriculture Organization, Roam, 144.

[7] Tripathi, R.P., Kushwaha, H.S. and Mishra, R.K. (1986) Irrigation Requirement of Rice under Shallow Water Table 
Conditions. Agriculture Water Management, 12, 127-136. http://dx.doi.org/10.1016/0378-3774(86)90011-9

[8] Tripathi, R.P. (1992) Water Management in Rice-Wheat System. In: Pandey, R.K., Dwivedi, B.S. and Sharma, A.K., Eds., Rice-Wheat Cropping System, Project Directorate for Cropping Systems Research, Modipuram, 134-147. Proceedings of Rice-Wheat Workshop, 15-16 October 1990, Modipuram, 277 p.

[9] Bajpai, R.K. and Tripathi, R.P. (2000) Evaluation of Non-Puddling under Shallow Water Tables and Alternative Tillage Methods on Soil and Crop Parameters in a Rice-Wheat System in Uttar Pradesh. Soil and Tillage Research, 55, 99-106. http://dx.doi.org/10.1016/S0167-1987(00)00111-2

[10] De Datta, S.K. (1981) Principles and Practices of Rice Production. John Wiley, New York, p. 618.

[11] Beser, N.S. (1999) The Effect of Water Stress on Grain and Total Biological Yield and Harvest Index in Rice (Oryzae sativa L). In: Chataigner, J., Ed., Future of Water Management for Rice in Mediterraneanclimate Areas: Proceedings of the Workshops, CIHEAM, Montpellier, 61-68.

[12] Bouman, B.A.M., Peng, S., Castaneda, A.R. and Visperas, R.M. (2005) Yield and Water Use of Irrigated Tropical Aerobic Rice Systems. Agricultural Water Management, 74, 87-105. http://dx.doi.org/10.1016/j.agwat.2004.11.007

[13] Mohyuddin, J. and Tarique, M. (2010) Evaluation of Irrigation Application Methods for Rice Production. Sarhad Journal of Agriculture, 26, 577-582

[14] Ashouri, M. (2012) The Effect of Water Saving Irrigation and Nitrogen Fertilizer on Rice Production in Paddy Fields of Iran. International Journal of Bioscience, Biochemistry and Bioinformatics, 2, 56-59. http://dx.doi.org/10.7763/IJBBB.2012.V2.70

[15] Kotter, E. (1968) Determination of Water Requirement of Rice in Laos. International Rice Commission Newsletter, 17, $13-20$.

[16] Indiaagronet (2005) Crop Planning Considering Water Requirements and Availability of Water. https://www.indiaagronet.com/indiaagronet/water management/CONTENTS/Crop\%20Planning.htm

[17] Bunyatta, D.K. (2012) Guideline for Growing New Rice for Africa (NERICA): An Upland Rice Variety as an Alternative Food Security Crop in Semiarid Lands of Kenya. Ministry of Agriculture, PDA’s Office Nairo Province, Nairobi.

[18] Adiam B.Z., Hadish, H. and Issak, T. (2013) Water Requirement, Growth and Yield of Four Rice Varieties at Hamelmalo Agricultural College. Senior Research Paper, Department of Land Resources and Environment, Hamelmalo Agricultural College, Hamelmalo, 40.

[19] Yang, C.M. (2012) Technologies to Improve Water Management for Rice Cultivation to Cope with Climate Change. Crop, Environment \& Bioinformatics, 9, 193-207.

[20] Ghildyal, B.P. and Tripathi, R.P. (1987) Soil Physics. Wiley Eastern Ltd. Publisher, New Delhi, 656 p.

[21] Obalum, S.E., Ezenne, G.I., Yoshinori, W. and Toshiyuki, W. (2011) Contemporary Global Issue of Rising Water Scarcity for Agriculture: The Quest for Effective and Feasible Soil Moisture and Free-Water Surface Conservation Strategies. Journal of Water Resource and Protection, 3, 166-175. http://dx.doi.org/10.4236/jwarp.2011.33021

[22] Behera, B.K., Varshney, B.P. and Goel, A.K. (2009) Effect of Puddling on Puddled Soil Characteristics and Performance of Self-Propelled Transplanter in Rice Crop. Agricultural Engineering International: The CIGRE Journal, 10, $1-18$.

[23] Rezaei, R., Tabatabaekoloor, M., Mousavi, S.R. and Aghili, N.N. (2012) Effects of Puddling Intensity on the In-Situ Engineering Properties of Paddy Field Soil. AJAE, 3, 22-26.

[24] Tripathi, R.P., Gaur, M.K. and Rawat, M.S. (2003) Puddling Effects on Soil Physical Properties and Rice Performance under Shallow Water Table Conditions of Tarai. Journal of the Indian Society of Soil Science, 51, 118-124.

[25] Sharma, P., Tripathi, R.P. and Singh, S. (2005) Tillage Effects on Soil Physical Properties and Performance of Rice-Wheat System under Shallow Water Table Conditions of Tarai, Northern India. European Journal of Agronomy, 23, 327-335. http://dx.doi.org/10.1016/j.eja.2005.01.003

[26] Guerra, L.C., Bhuiyan, S.I., Tuong, T.P. and Barker R. (1998) Producing More Rice with Less Water from Irrigated Systems. International Rice Research Institute, Manila.

[27] Singh, N.T., Patel, M.S., Singh, R. and Vig, A.C. (1980) Effect of Soil Compaction on Yield and Water Use Efficiency of Rice in Highly Permeable Soils. Agronomy Journal, 72, 499-502. http://dx.doi.org/10.2134/agronj1980.00021962007200030022x

[28] Jahan, M.S., Bin Nordin, M.N., Bin Che Lah, M.K. and Khanif, Y.M. (2013) Effects of Water Stress on Rice Production: Bioavailability of Potassium in Soil. Journal of Stress Physiology \& Biochemistry, 9, 97-107.

[29] Agrawal, R.P. and Kumar, R. (1976) Nitrogen Movement as Influenced by Initial Soil Wetness, Soil Texture and Soil Structure of Surface Layer. In: Sen, S.P., Abrol, Y.P. and Sinha, S.K., Eds., Nitrogen Assimilation and Crop Productivity Proceedings, National Symposium, Hissar, 260-268.

[30] Agrawal, R.P., Jhorar, B.S., Dhankar, J.S. and Raj, M. (1987) Compaction of Sandy Soils for Irrigation Management. 
Irrigation Science, 8, 227-232. http://dx.doi.org/10.1007/BF00257507

[31] Agrawal, R.P. (1991) Water Management in Sandy Soils by Compaction. Soil and Tillage Research, 19, 121-130. http://dx.doi.org/10.1016/0167-1987(91)90081-8

[32] Kirchhof, G. and So, H.B. (1996) The Effect of Puddling Intensity and Compaction on Soil Properties, Rice and Mung Bean Growth: A Mini-Rice Bed Study. In: Kirchhof, G. and So, H.B., Eds., Management of Clay Soils for Rain Fed Lowland Rice-Based Cropping Systems, ACIAR Proceedings No. 70, Proceedings of a workshop held at the Bureau of Soil and Water Management, Quezon City, Manila, 20-24 November 1995, 51-57.

[33] Sharma P.K. and Bhagat, R.M. (1993) Puddling and Compaction Effects on Water Permeability of Texturally Different Soils. Journal of the Indian Society of Soil Science, 41, 1-6.

[34] Humphreys, E., Muirhead, W.A., Fawcett, B.J., Townsend, J.T. and Murray, E.A. (1996) Puddling in Mechanised Rice Culture: Impacts on Water Use and the Productivity of Rice and Post-Rice Crops. Proceedings of the ACIAR International Workshop on Management of Clay Soils for Rainfed Lowland Rice-Based Cropping Systems, Manila, 24-25 November 1996, 213-218.

[35] Ladha, J.K. (2005) Improving the Recovery Efficiency of Fertilizer Nitrogen in Cereals. Journal of the Indian Society of Soil Science, 53, 472-483.

[36] Singh, R., Gajri, P.R., Gill, K.S. and Chaudhary, M.R. (2000) Soil and Fertilizer N Management for Sustainable Rice-Wheat Production. International Conference of Managing Natural Resources for Sustainable Agricultural Production in the 21st Century: Development and Conservation, 14-18 February 2000, New Delhi, 1358-1359.

[37] Javid, M.M., Qamar, A.R.Z. and Saleen, M. (1991) Effect of Different Levels of Compaction on Rice Grain Yield. Pakistan Journal of Agricultural Sciences, 28, 36-368.

[38] Tripathi, R.P., Ogbazghi, W., Amlesom, S. and Araia, W., (2014) Optimizing Tillage and Rain Water Conservation in the Soils of Hamelmalo Region of Eritrea for Arresting Soil Degradation and Achieving Sustainable High Crop Yields. Final Technical Report of the Project Financed by GEF/SGP, UNDP, Department of Land Resources and Environment, Hamelmalo Agricultural College, Keren, Eritrea, 112 p.

[39] NARI (National Agricultural Research Institute) Eritrea (2001-2003) Reports on Introduction of Conservation Agriculture in Eritrea, and Conservation Agriculture in Eritrea.

[40] Tripathi, R.P., Ogbazghi, W. and Amlesom, S. (2015) Rice Production Prospects in Eritrea. Journal of Water Resource and Protection, 7, 1429-1434. http://dx.doi.org/10.4236/jwarp.2015.717116

[41] FAO (1994) Agriculture Sector Review for Eritrea. FAO, Rome.

[42] MOA (Ministry of Agriculture) (2005) Area and Production by Zoba from 1992-2005.

[43] Tripathi, R.P., Ogbazghi, W., Amlsom, S. and Measho, S. (2016) Runoff Harvesting and Storage for Rice Crop at Hamelmalo, Semiarid Region of Eritrea. Computational Water, Energy, and Environmental Engineering, 5, 1-9. http://dx.doi.org/10.4236/cweee.2016.51001

[44] Tennant, D. (1975) A Test of Modified Line Intersect Method of Estimating Root Length. Journal of Ecology, 63, 995-1001. http://dx.doi.org/10.2307/2258617 